\title{
At the Crossroads of National and European Union Law. Experiences of National Judges in a Multi-level Legal Order
}

\author{
Urszula Jaremba*
}

\begin{abstract}
The notion and theory of legal pluralism have been witnessing an increasing interest on part of scholars. The theory that originates from the legal anthropological studies and is one of the major topical streams in the realm of socio-legal studies slowly but steady started to become a point of departure for other disciplines. Unavoidably it has also gained attention from the scholars in the realm of the law of the European Union. It is the aim of the present article to illustrate the legal reality in which the law of the Union and the national laws coexist and intertwine with each other and, subsequently, to provide some insight on the manner national judges personally construct their own understanding of this complex legal architecture and the problems they come across in that respect. In that sense, the present article not only illustrates the new, pluralistic legal environment that came into being with the founding of the Communities, later the European Union, but also adds another dimension to this by presenting selected, empirical data on how national judges in several Member States of the EU individually perceive, adapt to, experience and make sense of this reality of overlapping and intertwining legal orders. Thus, the principal aim of this article is to illustrate how the pluralistic legal system works in the mind of a national judge and to capture the more day-to-day legal reality by showing how the law works on the ground through the lived experiences of national judges.
\end{abstract}

Keywords: national judges, legal pluralism, application of EU law, legal consciousness, supremacy and direct effect of EU law

\footnotetext{
Urszula Jaremba, PhD, assistant professor at the Department of European Union Law, School of Law, Erasmus University Rotterdam. I am grateful to the editors of this Special Issue: Prof. Dr. Sanne Taekema and Dr. Wibo van Rossum as well as to the two anonymous reviewers for their useful comments. I am also indebted to Dr. Tobias Nowak for giving me his consent to use the data concerning the Dutch and German judges in this article. This article is mostly based on a doctoral research project that resulted in a doctoral manuscript titled 'Polish Civil Judges as European Union Law Judges: Knowledge, Experiences and Attitudes', defended on the 5th of October 2012.
}

\section{Introduction}

'Legal pluralism is everywhere. There is, in every social arena one examines, a seeming multiplicity of legal orders, from the lowest local level to the most expansive global level.' 'The notion and theory of legal pluralism, which is based on the idea that a society has more than one legal order, ${ }^{2}$ have been witnessing an increasing interest of scholars. The theory that originates from the legal anthropological studies and is one of the major topical streams in the realm of socio-legal studies ${ }^{3}$ slowly but steady started to become a point of departure for other disciplines. ${ }^{4}$ Unavoidably, it has also gained much attention from the scholars in the area of the law of the European Union (hereinafter the EU or the Union).

The European Union, which is based on the system of the Treaties, ${ }^{5}$ is a supranational transnational organization that goes beyond the nation-state ${ }^{6}$ and has its own regulatory regime that affects regulatory regimes of its Member States. What is more, in situation of conflicts between those legal regimes, it is the law of the Union

1. From B.Z. Tamanaha, 'Understanding Legal Pluralism: Past to Present, Local to Global', 30 Sydney Law Review, 375, at 375 (2008). See the author for the overview of the history of legal pluralism.

2. From D.J. Galligan, Law in Modern Society (2006), at 162. As claimed by the author, 'Legal pluralism is based on two ideas. One is that two or more legal orders can exists side-by-side within the same territory; the other is that legal systems derive from sources other than the state and exists as independent fields of law.'

3. See B. Dupret, 'Legal Pluralism, Plurality of Laws, and Legal Practices: Theories, Critiques, and Praxiological Re-specification', European Journal of Legal Studies, Issue 1, publicly available paper at <http://hal.inria .fr/ docs/ 00/ 17/ 84/ 22/ PDF/ 2007EjlsLegPlur .pdf> (last accessed 27 November 2012).

4. See A. Griffiths, 'Legal Pluralism', in R. Banakar and M. Travers (eds.), An Introduction to Law and Social Theory (2002) 289, on a comprehensive overview of the concept of legal pluralism and the scholarship in the area.

5. See Treaty on European Union (TEU) and Treaty on the Functioning of the European Union (TFEU).

6. See M.A. Pollack, 'Theorizing the European Union: International Organization, Domestic Polity or Experiment in New Governance?', 8 Annual Review of Political Science, 357, at 357 (2005). Referring to the EU as to an international organization is necessarily a simplification for the purposes of this article. Theorizing the European Union and its nature remains one of the most comprehensively discussed issues in the academic writing, in both legal and political science studies. There, the Union is referred to as a political organization, international organization, domestic political system, 'a unique experiment in governance beyond the national-state' or 'a new and emerging system of "governance without government"', see Pollack at 380. 
that is to take precedence over national laws. The 'multilevel nature of this supranational construct', ${ }^{7}$ which rests on competing legal claims originating from the interaction of national and EU 'regulatory spheres', poses one of the most intricate problems attached to this peculiar transnational legal structure. The existence of such a legal construct naturally brings another dimension to the notion of legal pluralism and implies, in this particular situation, a coexistence of two overlapping but autonomous legal orders with their own, but yet interconnected, judicial systems that can enforce compliance. ${ }^{9}$ Consequently, the notion of a legal order should be underscored since it distinguishes it from the situation of legal pluralism where both legal and nonlegal orders coexist. ${ }^{10}$ Paraphrasing Tamanaha, we are speaking here of a situation of legal pluralism where two official, positive, institutionalized legal systems coexist, which differentiate it from a situation where, for instance, religious and cultural normative orders coexist. ${ }^{11}$ In that respect, a somewhat narrow variant of legal pluralism is employed for the purpose of this article.

One of the most outstanding features of the law of the Union is the fact that it can produce rights and obligations not only for the contracting Member States but also for their citizens. ${ }^{12}$ However, while the EU Treaties create a system of judicial protection at the EU level, which is embodied in the Court of Justice of the EU (hereinafter CJEU or the Court of Justice), they are practically silent on the way the rights that individuals derive from Union's law should be protected. ${ }^{13}$ It occurs that disputes in which EU law is at stake and which arise between individuals and public authorities of the Member States, or between two or more private individuals, are to be heard in national courts and tribunals.

7. From M. Goldoni, 'Constitutional Pluralism and the Question of the European Common Good', 18 European Law Journal, 385, at 385 (2012).

8. From R. Wessel and J. Wouters, 'The Phenomenon of Multilevel Regulation: Interactions between Global, EU and National Regulatory Spheres. Towards a Research Agenda', in A. Follesdal, R. Wessel and J. Wouters (eds.), Multilevel Regulation and the EU (2007) 9, at 11. The authors' definition of regulation is a rather comprehensive one and refers to public and private rules, principles and standards that govern conduct, at 12 .

9. For purposes of the present article, legal pluralism is understood as 'legal reality consisting of multiple overlapping normative communities', from P. Schiff Berman, Global Legal Pluralism: A Jurisprudence of Law Beyond Borders (2012), at 1.

10. See Tamanaha, above n. 1, at 393

11. Ibid., at 397. The author lists five other systems of normative ordering, that is to say: customary/cultural, religious/cultural, economic/capitalist, functional and finally community/cultural which, in the words of the author, are different from the positive legal systems.

12. See Case 26-62, NV Algemene Transport en Expeditie Onderneming van Gend \& Loos v. Netherlands Inland Revenue Administration [1963] ECR 1.

13. Individuals can resort to the CJEU only to protect themselves against illegal actions of the EU, see Arts. 263, 265, 277 and 340 TFEU. In the context of the legality review, the access to the CJEU for individuals has been quite problematic for decades, see M. Eliantonio, 'Private Parties and the Annulment Procedure: Can the Gap in the European System of Judicial Protection be Closed?', 3 Journal of Politics and Law, 121 (2010). Art. 19 (1) TEU provides that Member States are to ensure sufficient and effective legal protection in the fields covered by Union law.
It is the underpinning premise of the system of judicial protection in the Union that those are the national courts that are expected to protect those rights and ensure effet utile of EU law. It is the national judge who has to function in this system of interacting, overlapping and at times conflicting legal orders, ${ }^{14}$ and it is the national judge who hears disputes in which state and non-state/EU legal sources may be applicable. In cases of substantive conflicts between both legal orders, it is the national judge who must find a solution and remedy the situation by, for instance, giving precedence to the law of the European Union or interpreting the national law in harmony with EU law. Those and many other tasks that are placed on national judges by EU law ${ }^{15}$ should be seen in the light of the fact that EU law has been increasingly affecting a great number of national legal realms. This implies that a great deal of legal norms that judges apply in their daily work origins either directly or indirectly from the law of the Union, whereby one would be inclined to assume that EU law has an enormous bearing on judicial practice whereby it has become a regular aspect of adjudication. By and large, all national courts are potentially decentralized EU courts and, consequently, all national judges are EU law judges expected to treat the law of the Union like national law and apply EU law in their daily work.

Nonetheless, the developments in the Member States show that the functioning of a national judge at the crossroads of national and EU law has not been easy. Examples from the jurisprudence of national (highest) courts illustrate how perplexing it has become to fulfill the task of a decentralized EU judge. ${ }^{16}$ Particularly, the doctrine of supremacy of EU law has not gained much

14. I. Pernice refers to 'two complementary constitutional layers, the European and the national, which are closely interwoven and interdependent', see I. Pernice, 'Multilevel Constitutionalism in the European Union', Working Paper 5/02, at 4, publicly available at <www.whi berlin.eu/documents/whi-paper0502.pdf> (last accessed 3 December 2012).

15. The EU-law-related tasks which the national courts are supposed to fulfill can hardly be found in the EU Treaties as they predominantly follow from the extensive jurisprudence of the Court of Justice.

16. Examples from different Member States show that national judges do not necessarily fulfill the expectations that are put on them by EU law and they may experience various problems in that regard. France seems one of good example illustrating the problem. Plötner claims that 'France is one of the Member States in which Community law has had the greatest difficulties to be fully integrated and recognised as supreme to national law.' See J. Plötner, 'Report on France', in A.-M. Slaughter, A. Stone Sweet and J.H.H. Weiler (eds.), European Court and National Courts - Doctrine and Jurisprudence: Legal Change in Its Social Context (1997), at 41; see also R. Mehdi, 'French Supreme Courts and European Union Law: Between Historical Compromise and Accepted Loyalty', 48 Common Market Law Review, 439 (2011). For the discussion on the potential obstacles to the fulfillment of EU law expectations by national judges, see also M. Bobek, 'On the Application of European Law in (Not Only) the Courts of the New Member States: Don't Do as I Say?', 10 Cambridge Yearbook of European Legal Studies, 1 (2007-2008); M. Bobek, 'A New Legal Order, or a Non-Existent One? Some (Early) Experiences in the Application of EU Law in Central Europe', 2 Croatian Yearbook of European Law and Policy, 265 (2006); Z. Kühn, 'The Application of European Law in the New Member States: Several (Early) Predictions', 6 German Law Journal, 563 (2005). 
applause on part of national courts. ${ }^{17}$ This is why the issue of legal pluralism in the EU has become a point of a considerably intense academic discussion. However, those very instructive contributions concerning the functioning of the multi-level constitutional order predominantly focus on the way national constitutional/ highest courts of the Member States participate (if at all) in the process of legal integration within the Union. ${ }^{18}$ The objective of the present article is different: it namely aims at, first, sketching the legal reality of two overlapping legal orders and, second and more importantly, providing some empirical insights regarding the way national private law judges function in and make

17. Several supreme national courts rejected the idea of absolutely supreme EU law in a rather straightforward manner. The never-ending skirmish between the CJEU and the national supreme courts concerning the issue of absolute supremacy and the ultimate authority to decide which law takes precedence (Kompetenz - Kompetenz) is well known and broadly discussed in the academic writing. Basically speaking, the discourse relates to the issue of the transfer of competences of Member States to the level of the European Union, and the limits to the participation of the state in the EU, but also the allocation of competences between national constitutional courts and the CJEU. As observed by Davies, 'The national courts, notably the Bundesverfassungsgericht, take the view that if EU law infringes aspects of the national constitution it will no longer apply on their territory, at least to the extent of infringement. The European Court of Justice, by contrast, claims that EU law is not subject to national constitutions. In the event of conflict, EU law should nevertheless be applied. Each court is correct according to its own legal order. Each is the authoritative interpreter of its own document, in the first case the national constitution and in the second case the European Treaties.' See G. Davies, 'Constitutional Disagreement in Europe and the Search for Pluralism', in J. Komarek and M. Avbelj (eds.), Constitutional Pluralism in Europe and Beyond (2012), at 272. See also M. Payandeh, 'Constitutional Review of EU Law after Honeywell: Contextualizing the Relationship between the German Constitutional Court and the EU Court of Justice', 48 Common Market Law Review, 9 (2011); G. Beck, 'The Lisbon Judgment of the German Constitutional Court, the Primacy of EU Law and the Problem of Kompetenz-Kompetenz: A Conflict between Right and Right in Which There Is No Praetor', 17 European Law Journal, 470 (2011); G. Martinico, 'Judging in the Multilevel Legal Order: Exploring the Techniques of Hidden Dialogue', 21 King's Law Journal, 257, at 259 (2010) and next. See also a recent judgment of the Czech Constitutional Court in case Landtová, PI. ÚS 5/12 (31 January 2012) in which the Czech court declared the decision of the CJEU ultra vires. The issue of primacy of EU law over national non-constitutional laws raises fewer concerns, and it can be stated that as such primacy of EU law over national sub-constitutional laws is now accepted by national highest courts. See L. F. M. Besselink, 'National and Constitutional Identity before and after Lisbon', 6 Utrecht Law Review, 36, at 46 (2010).

18. The theory of constitutional pluralism as developed in the realm of EU legal studies occupies the most prominent place in that group. As claimed by Martinico, 'In its simplest version, constitutional pluralism refers to a situation where several constitutional sites co-exist, each claiming authority.' See G. Martinico, above n. 17, at 259. For more, see, for instance, N.W. Barber, 'Legal Pluralism and the European Union', 12 European Law Journal, 306 (2006); G. Itzcovich, 'Legal Order, Legal Pluralism, Fundamental Principles. Europe and Its Law in Three Concepts', 18 European Law Journal, 358 (2012); Goldoni, above n. 7; M. Avbelj and J. Komarek, 'Four Visions of Constitutional Pluralism', 4 European Constitutional Law Review, 524 (2008); N. Walker, 'The Idea of Constitutional Pluralism', 65 Modern Law Review, 317 (2002); M. Kumm, 'The Jurisprudence of Constitutional Conflict: Constitutional Supremacy in Europe before and after the Constitutional Treaty', 11 European Law Journal, 262 (2005); M.P. Maduro, 'Contrapunctual Law: Europe's Constitutional Pluralism in Action', in N. Walker (ed.), Sovereignty in Transition (2003) 501; G. Davies, 'International Trade, Extraterritorial Power, and Global Constitutionalism: A Perspective from Constitutional Pluralism', 13 German Law Journal, 1203 (2012). sense of this peculiar legal environment. Also, the (potential) problems that are the consequence of this pluralistic order are brought to the fore. Hence, the core of this article is to assess and understand how national private law judges individually place themselves in the pluralistic legal environment. The following questions are addressed in this contribution: what is the actual role of EU law in the daily practice of national courts? What is the knowledge of EU law and the reception of the legal order of the European Union among national judges? What are the problems attached to the functioning in such a multi-leveled and heterogeneous legal order? The subsequent discussion is therefore not aimed at answering the question how judges resolve specific legal problems and apply (EU) law to cases at hand, but at providing insights regarding the way they observe and construct the legality of EU law and how they see the relevance of $\mathrm{EU}$ law for their daily practice. In that sense, this contribution not only provides a theoretical view on the way EU law interacts with national law, but also offers several illustrative, pragmatically oriented examples of how national judges perceive the role of EU law and experience it in the daily practice.

The above questions are not easy to be addressed, and a mere black-letter analysis of national case-law is not capable of providing adequate answers to them. They imply the necessity of going beyond the scene of formal law and employing an interdisciplinary approach and methodology. For the purposes of the present article, empirical data that originate from larger socio-legal studies conducted among national civil judges of lower courts in Germany, the Netherlands and Poland are used. These data illustrate the way national judges individually and personally establish their own understanding of the legal system in which laws of state and nonstate origin coexist, intertwine and interact with each other and at the same time are autonomous. Also the problems they come across while dealing with the EU law sources are brought to the fore. For the purposes of the empirical part of the study, several elements of the theory of legal consciousness are borrowed and applied.

This article will first discuss the theory of legal consciousness, which constituted the theoretical underpinning of the above-mentioned empirical studies among national judges. Next, the nature of the legal order of the European Union and the role of the national judge in enforcing EU law seen from the theoretical point of view will be illustrated. Subsequently, insights regarding the way national judges of lower courts in Germany, the Netherlands and Poland experience the law of the Union and the multi-level legal order will be presented. This part will necessarily be preceded by a short introduction regarding the methodological approach applied in the empirical study. In the concluding remarks, it will be attempted to bridge the theoretical perspective with the empirical insights. 


\section{Theoretical Framework: Legal Consciousness and the Law-in-Mind}

Following Hart's concept of law, it could be claimed that a set of rules forms law if state officials regard those rules as binding and adapt the internal view towards those rules. ${ }^{19}$ It is also generally claimed that state officials in modern legal systems accept the authority of the state law and consequently apply it. ${ }^{20}$ This assumption can, however, be challenged if one considers the issue of legal pluralism, and more precisely the way state official accept the authority of non-state law, including supranational law. Law-and-society theory highlights the (social) consequences of legal pluralism and parallel and intertwining legal orders. It also emphasises the necessity of exploring how those different and intersecting legal dimensions affect the behaviour of state officials and their attitudes and approach towards it. ${ }^{21}$ The latter terrain of legal pluralism is, however, addressed to a somewhat limited extent. ${ }^{22}$

Exploring the way state officials place themselves in the pluralist legal order, approach it and deal with it is a daunting exercise from both theoretical and methodological point of view. To address this problem, the larger empirical studies loosely drew on the theory of legal consciousness. $^{23}$ The notion of legal consciousness is a comprehensive one and has various dimensions but, in general, refers to the process of perception and understanding of the role of law, and the process of compliance with law by individuals. ${ }^{24}$ Legal consciousness focuses on what individuals know about the $\mathrm{law}^{25}$ and the way the law is approached, invoked and used by them. As claimed by Ewick and Silbey, the phrase legal consciousness is used to 'name participation in the process of constructing legality.' 26 In their research, the

19. See H.L.A. Hart, The Concept of Law, 3rd edn (2012).

20. See Galligan, above n. 2, at 295.

21. Ibid., at 169-172.

22. One of the existing examples is a study regarding Indonesian judges and the dilemmas they encounter when they decide cases on the basis of competing (customary, state, religious) legal orders; see J.R. Bowen, 'Consensus and Suspicion: Judicial Reasoning and Social Change in an Indonesian Society 1960-1994', 34 Law \& Society Review, 97 (2000).

23. It is claimed that legal consciousness scholarship originates from the socio-legal scholarship concerning legal culture, see D. Engel, 'How Does Law Matter in the Constitution of Legal Consciousness?', in B. Garth and A. Sarat (eds.), How Does Law Matter (1998) 109, at 126.

24. See D.J. Galligan, above n. 2, at 336 and next. The author lists six 'senses' of legal consciousness.

25. See M. Hertogh, 'A "European" Conception of Legal Consciousness: Rediscovering Eugen Ehrlich', 31 Journal of Law and Society, 457, at 461 (2004).

26. See P. Ewick and S.S. Silbey, The Common Place of Law. Stories from Everyday Life (1998), at 45. The concept of legality is distinct from the concept of the law. The legality refers to the way legal institutions are shaped and translated in everyday action. See also P. Ewick and S.S. Silbey, 'Conformity, Contestation, and Resistance: An Account of Legal Consciousness', 26 New England Law Review, 731 (1992), and S.S. Silbey, 'After Legal Consciousness', 1 Annual Review of Law and Social Science, 323 (2005), who reflects on the whole range of research conducted in the field of legal consciousness. authors dealt with ordinary citizen's (lay people) understanding of law and the varieties of legal consciousness that they revealed. ${ }^{27} \mathrm{By}$ and large, they explored how different people imagine, use, respond to, invoke and experience the law and thereby constructed and confirmed a certain kind of legality. ${ }^{28}$ Hence, legal consciousness concerns not only the way people behave but also their attitudes with regard to the legal actions that may be undertaken. ${ }^{29}$ Yet, as observed by Ewick and Silbey, in order to know how the law is resorted to it is necessary to know not only why, when and how the law and legal institutions are used, but also why and when they are not used. ${ }^{30}$ All in all, the notion of legal consciousness is used in order to identify the manner particular individuals understand what the law is, experience it and respond to it. ${ }^{31}$

For the purposes of the larger empirical studies among the national judges, the theory of legal consciousness was considerably narrowed down in order to discern what the judges know about EU law, how they see, respond to and make use of it, and how they try to come to grips with the multi-level legal order in the day-today reality. It was therefore focused on the manner judges personally perceive the role of the law of the Union, deal with it (if at all) in their daily practice and understand how the pluralistic legal system works. One can of course pose a question of reasonableness of exploring legal consciousness of judges. The most important and obvious reason of doing so is the fact that law plays a completely different role in professional activities of judges than it plays in lives of lay people. Law is a self-evident and permanent part of the practice of courts, and judges are supposed to know the law and be the mouth of it. ${ }^{32}$ For a lay person, the law is an intrusive and mostly remote aspect of her life. ${ }^{33}$ Therefore, legal consciousness of a judge has necessarily a different dimension than that of an ordinary citizen. In case of the judiciary, one can speak of legal consciousness, which is 'internal' to the system of law and which

27. The authors collected accounts of the law from more than 400 US citizens originating from different social and ethnic classes and with different educational backgrounds. On the basis of those accounts, they distinguished different forms of legal consciousness.

28. See also International Encyclopedia of Social and Behavioral Sciences (2001), at 8626, where it is stated that '[...] the study of legal consciousness traces the ways in which law is experienced and interpreted by specific individuals as they engage, avoid, or resist the law and legal meanings'

29. See E.A. Hoffmann, 'Legal Consciousness and Dispute Resolution: Different Disputing Behavior at Two Similar Taxicab Companies', 28 Law \& Social Inquiry, 691, at 694 (2003).

30. See Ewick and Silbey (1992), above n. 26, at 737.

31. For more on legal consciousness see also, A.E. Merry, 'The Discourses of Mediation and the Power of Naming', 2 Yale Journal of Law and the Humanities, 1 (1990); E.W. Larson, ‘Institutionalizing Legal Consciousness: Regulation and the Embedding of Market Participants in the Securities Industry in Ghana and Fiji', 38 Law \& Society Review, 737 (2004); L.B. Nielsen, 'Situating Legal Consciousness; Experiences and Attitudes of Ordinary Citizens about Law and Street Harassment', 34 Law \& Society Review, 1055 (2000); Hertogh, above n. 25; A. Blackstone, C. Uggen and H. McLaughlin, 'Legal Consciousness and Responses to Sexual Harassment', 43 Law \& Society Review, 631 (2009).

32. C.-L. Montesquieu, De l'esprit des lois. Tome premier (1832), at 99.

33. See Ewick and Silbey (1998), above n. 26, at 15. 
stands in contrast to its 'external' dimension, which is presented by ordinary citizens. ${ }^{34}$ For that purpose, the 'the law first perspective' was applied in the respective empirical studies. ${ }^{35} \mathrm{By}$ and large, the premises of the legal consciousness theory were narrowed down and reformulated in order to fit the specific circumstances of the current research, but the final objective of the empirical exercise remained within the general framework of the legal consciousness theory, that is to say it focused on discerning how people (judges) approach, use, respond to, invoke and experience (EU) law. Before presenting several empirical insights regarding the way ordinary judges of lower civil courts in the three respective Member States construct their own understating of overlapping legal orders, and the problems that are entailed by this complex legal environment, the issue of the relationship between national and EU law and the consequences of that for national judges seen from the theoretical point of view are discussed.

\section{The Relationship between National and EU Law and the Consequences for National Judges}

The question of how EU law interacts with national laws and the consequences of that for national courts is definitely an absorbing but also a subtle and complex issue that revolves around inter alia two invariably controversial legal notions, i.e. direct effect and primacy of EU law. Therefore, considering the issue of the legal nature of EU law and its relationship with national laws in a brief and concise manner remains a daunting exercise. What is more, those pivotal constitutional features of the law of the Union can hardly be found in the Treaties as they origin from the case-law of the CJEU.

The Costa v. ENEL judgment - one of the most groundbreaking judgments of the Court of Justice seems to adequately illustrate the complex nature of the law of the European Union and its relationship with national laws. ${ }^{36}$ From the judgment it follows that the Member States agreed to lose some of their state authority as they consented to transfer some of their sovereign powers to the supranational unit, which in consequence implies that EU has its own regulatory regime. Furthermore, EU law forms an autonomous legal order that is

34. Consequently, one can also speak of two kinds of legal culture: external legal culture among ordinary people, and the internal legal culture to be found among those who perform law related tasks in the society, see L.M. Friedman, 'Law, Lawyers, and Popular Culture', 98 The Yale Law Journal, 1579, at 1580 (1989).

35. Silbey (2005), above n. 26, at 348 and 355. In case of popular legal consciousness, the authors focus on normal, daily life of people to see how legal institutions and concepts are reflected therein. In that sense, the so-called law-first perspective is avoided.

36. Case 6/64, Flaminio COSTA v. ENEL [1964] ECR 00585, paras. 3 and 7 of the summary. different from international law and which constitutes an integral part of the national legal order and bounds not only the 28 contracting Member States but also its citizens. In that sense, its provisions are capable of producing direct effect for individuals, i.e. they can directly be invoked and relied upon by individuals before national courts, provided that those provisions are clear, precise and unconditional. ${ }^{37}$ In case of a collision of the national legal norms with the provisions of EU law, the latter shall take precedence, ${ }^{38}$ provided that the dispute falls within the scope of EU law. ${ }^{39}$ Accordingly, in case of collision between a national and EU norm, the former one should be set aside, regardless of its place in the national legal order and the time of its enactment. Costa v. ENEL clearly illustrates that collisions between EU and national law are possible and practically unavoidable. ${ }^{40}$ Yet, the story of direct effect and primacy of EU law does not end here. Since the principle of direct effect has different bearing on different sources of EU law ${ }^{41}$ and, consequently, it cannot be accorded to all EU law provisions, ${ }^{42}$ the principle to interpret national law as far as possible in conformity with EU law was devel-

37. The requirement of an EU law provision to be sufficiently clear, precise and unconditional in order to produce direct effect was established by the Court of Justice in Van Gend \& Loos case, above n. 12. The concept of direct effect remains one of the central and at the same time one of most complex and ambiguous concepts of EU law. For more, see P. Craig and G. De Búrca, EU Law: Text, Cases and Materials, 4th edn (2008), at 269 and next.

38. As claimed by the ECJ, EU law takes precedence over any national provision, also the one of constitutional nature, and applies independent of the date of the respective national provision, whether prior or subsequent to the EU law rule. See Cases 11/70, Internationale Handelsgesellschaft $\mathrm{mbH}$ v. Einfuhr- und Vorratsstelle für Getreide und Futtemittel [1970] ECR 1125, para. 3, and 106/77, Amministrazione delle Finanze dello Stato v. Simmenthal SpA [1978] ECR 629, para. 21 respectively.

39. It is not entirely clear when a case falls within the scope of EU law. Member States are bound by the EU norms when they implement and enforce EU law, but also when they derogate from EU law provisions, see Case C-260/89, Elliniki Radiophonia Tileorassi Anonimi Etairia (ERT AE) [1991] ECR I-2951.

40. From M. Goldoni, 'Constitutional Pluralism and the Question of the European Common Good', 18 European Law Journal, 385, at 396 (2012).

41. The Union's legal order rests on various and distinct legal sources, each having different effect in the national legal order. Hierarchically, the sources are formed by primary EU law which can be found in the EU Treaties, general principles of Union law, international agreements that the Union has concluded, and secondary EU law consisting of regulations, directives and decisions. Furthermore, there are non-binding sources of soft-law such as recommendations and opinions. Next to that, the interpretations of EU law which are given by the CJEU are binding on national courts and administrative authorities.

42. For instance, those provisions that lack sufficient precision or those that are enshrined in EU directives and are invoked in disputes between private individuals. In Case 152/84, Marshall v. Southampton and SouthWest Hampshire Area Health Authority [1986] ECR 727, the Court of Justice held that individuals can rely on EU directives only against the State, not against another individual. 
oped by the Court of Justice. ${ }^{43}$ Basically speaking, this principle implies that domestic legal provisions have to be construed consistently with EU law.

The foregoing discussion with regard to the nature of the relationship between national and Union law should be seen in the light of a very extensive scope of EU regulatory activities. The spectrum of EU law is increasingly growing covering not only issues such as taxes, customs, competition law, financial services, ${ }^{44}$ company law, ${ }^{45}$ non-discrimination and employment relationships ${ }^{46}$ but also consumer protection and contract law, ${ }^{47}$ immigration issues and criminal laws. ${ }^{48}$ Likewise the national procedure has witnessed increasingly more impact of EU law by means of EU regulations. ${ }^{49}$ In fact, one may argue that there is virtually no realm of national law that has not been affected by regulatory activities of the Union. Differently stated, a gross of provisions that national authorities and judges apply stems from

43. See Case 14/83, Von Colson and Kamann v. Land Nordrhein-Westfalen, [1984] ECR 1981, para. 28 in which the Court of Justice held that the legislation adopted to implement the directive at issue has to be interpreted in conformity with EU law. This obligation applies not only to national legislation implementing the directive in question but to all national law, see Case C-106/89, Marleasing SA v. La Comercial Internacionale de Alimentacion SA [1990] ECR I-4135. This doctrine of harmonious interpretation has been broadened to the Treaties provisions, general principles of EU law, international agreements concluded by the Union and even to soft law sources of EU law.

44. See for instance Council Directive 79/279/EEC of 5 March 1979 coordinating the conditions for the admission of securities to official stock exchange listing; Council Directive 87/344/EEC of 22 June 1987 on the coordination of laws, regulations and administrative provisions relating to legal expenses insurance or Directive 98/29/EC of 7 May 1998 on the harmonisation of the main provisions concerning export credit insurance for transactions with medium and long-term cover.

45. See for instance Third Council Directive 78/855/EEC of 9 October 1978 concerning mergers of public limited liability companies; Twelfth Council Company Directive 89/667/EEC of 21 December 1989 on singlemember private limited-liability companies; Directive 2005/56/EC of the European Parliament and of the Council of 26 October 2005 on cross-border mergers of limited liability companies.

46. See for instance Directive 76/207/EEC on the implementation of the principle of equal treatment for men and women as regards access to employment, vocational training and promotion, and working conditions as amended by Directive 2002/73/EC of the European Parliament and of the Council of 23 September 2002; Directive 2000/43/EC of 29 June 2000 implementing the principle of equal treatment between persons irrespective of racial or ethnic origin; Council Directive, or Directive 2003/88/EC of the European Parliament and of the Council of 4 November 2003 concerning certain aspects of the organisation of working time.

47. See for instance Directive 85/374/EEC of 25 July 1985 on the approximation of the laws, regulations and administrative provisions of the Member States concerning liability for defective products as amended by Directive 1999/34/EC; Council Directive 85/577/EEC of 20 December 1985 to protect the consumer in respect of contracts negotiated away from business premises, or Council Directive 90/314/EEC of 13 June 1990 on package travel, package holidays and package tours.

48. On the influence of EU law in the criminal law area, see M. Fletcher, R. Lööf, B. Gilmore and W.C. Gilmore, EU Criminal Law and Justice (2008).

49. See for instance Regulation (EC) No. 1348/2000 of the Council of 29 May 2000 on the service in the Member States of judicial and extrajudicial documents in civil or commercial matters or Regulation (EC) No. 1896/2006 of 12 December 2006 of the Council and European Parliament creating a European Order for Payment Procedure.
EU law. ${ }^{50}$ This expanding process of Europeanisation has led to the increase of the number of legal sources and a rapid transformation of national laws in various fields.

It is against this background that the role of the national judge comes to the fore. By and large, the European Union expects much from the national judge. It gives her new responsibilities and competences, but it also imposes new obligations and expectations on her. ${ }^{51}$ Seen from a different angle, those tasks empower the judge by giving new legal mechanisms at her disposal. The above-discussed doctrines, seen together with the principle of state liability in damages for infringements of $\mathrm{EU} \mathrm{law}^{52}$ and the preliminary ruling procedure that is enshrined in Article 267 TFEU, are constitutive instruments that allow national judges to undertake judicial actions that are normally non-existent under national constitutional and procedural legal frameworks.

The foregoing sketches an absorbing picture of a national judge who is familiar with the sources of EU law, resorts to them and applies them daily. What is more, she is expected to read EU sources in other official languages of the European Union in order to compare them. ${ }^{53}$ She assures the direct effect to EU provisions and sets aside national rules that conflict with EU law. She raises EU law points of her own motion and applies EU law ex officio to the extent that similar obligation exists under national law or if the public interest so demands. ${ }^{54}$ She willingly refers her questions concerning the interpretation or validity of EU law to the CJEU, which is for her the highest judicial authority with regard to EU law. She interprets national rules in the entire context of EU integration in order to achieve the objectives of EU law, its effectiveness and uniformi-

50. Many of those norms are directly applicable EU law provisions that stem from EU regulations but a considerable number of those norms constitute national implementation of EU directives. Scholars and practitioners are not in agreement with regard to the scope of the influence of EU law on national law. Whereas some authors claim that as much as 80 per cent of the national legislation constitutes implementation of EU law, others suggest that number is much lower. In 2010, the body of EU law consisted of approximately 8,400 regulations and nearly 2,000 directives, in addition to the Treaties From 28th Annual Report on monitoring of the application of EU law (2010), COM (2011) 588 final, at 3. It should not be forgotten that the legislative body includes binding decisions and a large body of soft law acts.

51. As claimed by $M$. Bobek '[...] national judges are said to have "mandate" under EC law; they are "empowered" by EC law, or, in the less thrilling version of the story, they just become "Community judges'", see M. Bobek, 'The New European Judges and the Limits of the Possible', in A. Łazowski (ed.), The Application of EU Law in the New Member States. Brave New World (2010), at 127.

52. See joined cases C-6/90, Francovich and Bonifaci v. Republic of Italy [1991] ECR I-5375.

53. See case 283/81, Srl CILFIT and Lanificio di Gavardo SpA v. Ministry of Health [1982] ECR 0341, para. 16.

54. See joined cases C-430/93 and C-431/93, Jeroen van Schijndel and Johannes Nicolaas Cornelis van Veen v. Stichting Pensioenfonds voor Fysiotherapeuten [1995] ECR I-04705; C-126/97, ECo Swiss China Time Ltd v. Benetton International NV [1999] ECR I-3055, paras. 36-37. 
ty across all the Member States. ${ }^{55}$ In order to achieve all the above-mentioned, the national judge adopts different methodology and tools, such as for instance teleological and systemic method.

From the above considerations, it follows that the national judge plays a pivotal role in the multi-level legal order. ${ }^{56}$ One can conclude that all national judges, regardless of their specialization and position in the national judicial architecture, are EU law judges. They are entrusted with the constitutive task of ensuring the effet utile of EU law and its uniform application. The process of legal integration within the Union and further development of its legal order very much depends on judges' willingness to cooperate and contribute to this supranational legal order. However, it must be stressed that somewhat little is known about the general reception of EU law by national judges of lower instance courts, the factual impact of EU law on their daily practice, and the potential obstacles national judges come across while exercising their EU law competences. It is the very aim of the following sections to provide some insights with regard to those inquiries. Prior to that, the methodological approach that was applied in the larger empirical studies is sketched.

\section{The National Judge in a Multi-Level Legal Order: Individual Experiences}

\subsection{The Mixed-Method Approach and Its Limitations}

Both quantitative and qualitative empirical data that will be presented below were collected in the course of two socio-legal studies among national judges of lower courts adjudicating in the area of private law. ${ }^{57}$ Judges in three EU jurisdictions, namely, Germany, the Netherlands and Poland were the object of two parallel

55. A national court has to interpret national laws in conformity with EU law 'in so far as it is given discretion to do so under national law', see case Von Colson, above n. 43, para. 28, but this obligation cannot serve as the basis for an interpretation of national law contra legemsee Case C-212/04, Konstantions Adeneler and others v. Ellinikos Organisamos Galaktos (ELOG) [2006] I-06057, para. 110.

56. See Martinico (2010), above n. 17, at 257

57. A broad notion of private law was adopted for the purposes of the study which implies that also judges adjudicating in the area of employment and social security and commercial law were included. In case of Poland district courts (sad rejonowy) and regional courts (sad okręgowy) were included in the study, in the Netherlands district courts (rechtbanken) and appeal courts (gerechtshoven) were included in the study and in Germany higher regional courts (Oberlandesgericht), district courts (Landengerichte), local courts (Amtsgerichte), higher labour courts (Landesarbeitgerichte) and labour courts (Arbeitsgerichte) were included in the study. empirical projects. ${ }^{58}$ The choice of civil jurisdiction was motivated by the fact that the process of Europeanisation of national private laws is quite a novel phenomenon and not much research has yet been done in this area. ${ }^{59}$ It should be underscored that the way EU law affects the area of private law has a different dimension than in the area of administrative law. Private law started to be affected by EU law only in the course of the last two decades and in a fragmented way, which implies that it still is a somewhat novel phenomenon and that national judges do not necessarily regularly come across it in their daily practice. Hence, the results of the empirical research and the conclusions following therefrom should not be stretched to other fields of adjudication.

For the purposes of the data collection, a mixed-method approach was adopted that was based on a distribution of a comprehensive questionnaire among the national judges and, subsequently, on semi-structured, in-depth interviews with a limited number of them. ${ }^{60}$ The questionnaire and interviews were focused on three general clusters of variables that related to the knowledge of EU law among the judges, their experiences with it in the daily practice, and their attitudes to EU law. This enabled to not only base the research on generalizable data, but also look behind those data in order to find out how judges experience their role in relation to EU law. It was therefore possible to probe for questions like how often judges resort to or use EU law in their daily practice, but also why they do or do not resort to it and use it. The interviews also made it possible to discern the problems judges come across daily while dealing with the pluralistic legal order.

In case of Poland, 373 questionnaires were filled in, out of which 300 in their entirety. Eventually 313 questionnaires were included in the analysis, of which 281 are entirely filled out. Subsequently, 25 interviews were conducted with those judges who give their consent to participate in the qualitative part of the study. In case of Germany, 190 private law judges from the region of North Rhine-Westphalia took part in the quantitative part of the study and 103 questionnaires were completed. In the Netherlands, 146 private law judges filled out the questionnaire, 127 of which were filled out in their entirety. Subsequently, seventeen interviews with Dutch judges and eleven with German judges were conducted. ${ }^{61}$

58. The data with regard to the German and Dutch judges originate from the empirical project by T. Nowak, F. Amtenbrink, M. Hertogh and M. Wissink, National Judges as European Union Judges. Knowledge, Experiences and Attitudes of Lower Court Judges in Germany and the Netherlands (2011). The project with regard to the Polish civil judiciary by the author of this contribution has borrowed the methodological and theoretical premises from the original project for Germany and the Netherlands.

59. Administrative courts and the application of EU law by them have traditionally been in the center of the academic attention.

60. For more on mixed approach see A. Tashakorri and C. Teddlie, Combining Qualitative and Quantitative Approaches (1998).

61. The data collection circle in Poland took place between October 2009 and June 2010. For the methodological details in case of Germany and the Netherlands, see Nowak et al., above n. 58, at 18 and next. 
In the next section, the focus is put on those elements of the larger empirical projects that answer the main research question relating to assessing and understanding how national private law judges place themselves in the pluralistic legal order of Europe. How relevant is the supranational legal order of Europe vis-a-vis their national law, in the eyes of judges? How much do they know of EU law and what is their assessment of the impact of EU law? How do judges look at the relevance of decisions of the European Court of Justice? By presenting a selection of the data and especially by using quotes from the interviews, several insights with regard to the way judges deal with non-state (EU) law are provided. In that sense, the interviews offer a colorful and nuanced illustration of the way the judges perceive and approach the law that they are expected to apply and reflect on the factual gap between the law it ought to be and the law in action. It should be underscored that the presented data are of empirical nature, which means that it is refrained from giving a judgment over what the respondents said. Moreover, the interviews were conducted in an ordinary, non-legal language, whereby it was tried to capture the respondents' personal attitude in order to come as close as possible to the manner national judges construct their own understanding of EU law. For the foregoing reasons, interview fragments may seem paradoxical or amusing. ${ }^{62}$

It should be stressed that the interview material reflects the subjective perspective of a relatively small sample of judges. These findings should not be generalized since the representativeness of the sample for the entire national judiciaries is not fully certain. ${ }^{63}$ However, since not much research of this nature has yet been conducted, it seems highly relevant to present the insights of the explorative research. As a last methodological point, it should be emphasised that the judges who participated in the empirical study were assured full anonymity and for that reason no personal attributes and data are disclosed in the following sections.

\subsection{The Role of EU Law in the Daily Judicial Practice: Abstractness and Remoteness of the Legal Order of the Union}

How do national civil judges in the respective Member States see the relevance of EU law for their daily practice and what significance do they attach to it? Those two constitutive questions will shortly be addressed below. As mentioned earlier, one could assume that judges are dealing with EU law sources on a daily basis due to the extensiveness of EU regulatory activities, which immensely affects the national legal orders. Nonetheless, the data show to the contrary. From the studies, it clearly occurred that in principle national private law judges deal with EU law issues on a somewhat infrequent basis. According to the Polish survey, 41 per

62. Some nuances from the interviews can, however, be lost due to its necessary translation from the original language to English.

63. See for similar problems A. Sarat and W.L.F. Felstiner, 'Lawyers and Legal Consciousness: Law Talk in the Divorce Lawyer's Office', 98 The Yale Law Journal, 1663, at 1669 (1989). cent of the judges did not deal with any EU-law-related case in the preceding twelve months, and only 5 per cent dealt with a relatively high number of cases involving EU law. ${ }^{64}$ In particular, the Polish judges expressed their ideas of EU law being a somewhat remote and abstract or even irrelevant aspect of the daily adjudication. Those meager practical experiences with resorting to and applying EU law seem to result in a significant number of judges who take a rather ambivalent stance towards the entire issue. The following statement of one of the Polish judges seems to adequately reflect on the foregoing:

My contact with EU law is very marginal so the whole issue remains a rather abstract one. It is different, interesting but irrelevant.

Other interviewed judges observed that the fact of the infrequent occurrence of EU law in their daily practice is at the same time one of the major problems attached to it. Simply stated, EU law is not perceived as living law or as something that has a real bearing on the daily practice. As declared by another Polish judge:

The infrequency of the occurrence of EU law is actually one of the biggest problems attached to it. If one case in a thousand cases has to do with EU law then you do not associate this law with something that is relevant, something that you can establish clear links with.

This state of affairs in Poland can partly be explained by the fact of a rather short membership of the country in the Union. However, also the results for the Netherlands and Germany - both founding Member States of the Communities/EU - show that, even though the judges in both countries have somewhat wider experiences with EU law, the relevance thereof for the daily practice remains, in general, relatively limited. ${ }^{65}$ A German judge refers to the lack of need to resort to EU law:

The German judge has a fully functioning body of national law; he has therefore no need for European law. ${ }^{66}$

Another German judge seems to somewhat undermine the relevance of EU law for the daily practice of a judge:

Of course I do not know all the rules [of national law] but would have no problems finding information about the problem. This would be more trouble in

64. High number implies 20 or more cases per year in which EU law played a role. From another inquiry, it follows that approximately 40 per cent of the Polish judges have not ever dealt with any EU law issue in practice.

65. Eighty-five per cent of the Dutch and 71 per cent of the German judges dealt with at least one EU law case in the course of the twelve preceding months. It also occurred that in both Germany and the Netherlands there is a group of judges that amounted to 10 per cent of the surveyed population, which deal with EU law more frequently, that is to say in 26 and more cases a year; see Nowak et al., above n. 58, at 38 and next.

66. Nowak et al., above n. 58, at 39. 
European law. The distance is much bigger. After all EU law is one important legal basis but only one of many. ${ }^{67}$

Also the opinion of one of the Dutch judges seems to fit the above picture:

I always found it interesting but never found an application for it. You do not come across it in your work. $^{68}$

Another Dutch judge who has never dealt with EU law in practice concedes:

So far I haven't had any real request to use a European ruling. ${ }^{69}$

Interestingly, both quantitative and qualitative data disclosed that the parties to the proceedings may yet not be eager to reach for EU law sources and rather infrequently signal that their dispute might involve some aspects thereof. A Polish judge says:

EU law requires much engagement but since we know our national law so well we lack determination to consult EU material law or the jurisprudence of the CJEU directly. It's a system of connected vessels: the parties do not touch upon it so we don't deliberate whether EU should be applied. We don't split hairs and we simply apply national rules. And if the parties do not refer to it then nobody is going to be bothered.

At the same time, many of the surveyed Polish judges were of the opinion that it is the role of the parties to the proceedings to bring EU law aspects to the fore. Consequently, if they do not do it then it is useless to make effort and go beyond what is well known and directly at the disposal of the judge, that is to say national law. ${ }^{70}$ In that sense, judges may assume that national law is directly at their reach, it is something they are 'embedded in' and should therefore be applied first.

There are very few cases where EU could play a role. If we don't have to then we do not resort to European law. If the parties do not refer to EU law and there are no doubts in national law why shall you bother and resort to EU law and EU directives? [...] Here we mostly make use of national law. And that's enough for us.

This abstractness of EU law and its seemingly scant relevance for the daily practice results in a stronger

67. Ibid., at 47

68. Ibid., at 39

69. Ibid., at 44

70. It should be yet emphasized that a stark contrast in the way Polish civil judges see the problem was detected. Many observed that it is the role of the judge to know the applicable rules regardless of their origin and apply them if a case so requires. This is also supported by the national doctrine and the procedural rules in Poland. attachment to the local (national) legal order and the national sources of law. Those are also directly at the disposal of a national judge and do not require from her any additional work attached to looking for, consulting and interpreting the sources of EU law. In that respect, also the fact of procedural economy attached to timeconstraints was brought to the fore. Resorting to the law of the Union and applying it to the case implies additional work, effort and consequently the necessity of spending more time on a single case. A German judge declares:

You don't help them [the parties] - and I do not have the time for it - with research that takes hours. ${ }^{71}$

All in all, it can be concluded that the theoretical assumption that judges deal with EU law on the daily and frequent basis seem, at least in case of private law judges of lower courts, somewhat inapt. Certainly, this is only one side of the story and in order to get a full picture of the situation it is necessary to investigate the reasons of this relatively infrequent occurrence of EU law in the daily practice. Those seem to be connected not only to the already mentioned passive attitude of the parties to the proceedings but also to the fact of lack of EU law knowledge among judges, which is, in turn, partly caused by the extensiveness of the EU regulation.

\subsection{Lack of Knowledge of EU Law}

The problem of infrequent occurrence of EU law in the daily practice seems to go together with the fact that for a national judge of a lower court it is quite perplexing to get familiar with EU law and to keep pace with the developments therein. The quantitative data for all three countries are very telling in that respect. Only 23 per cent of the Polish judges declared to be wellinformed with regard to the new developments in EU law, whereas 88 per cent declared to be well-informed about changes in national law. In a similar vein, 92 per cent thought to have a (very) good knowledge of national law, whereas only 12 per cent had such an opinion with regard to EU law. Furthermore, as much as 42 per cent stated that their knowledge of EU law was (very) poor. Also the German and Dutch judges admitted that their knowledge of EU law is significantly weaker than that of national law. Twenty per cent of German and Dutch judges declared to be well informed with regard to the developments in EU law. ${ }^{72}$ Likewise, only 12 per cent of them assessed their knowledge of EU law as (very) good. It is evident that in all three countries, it is the minority of the group that finds their knowledge of EU law satisfying. Yet it necessarily has to be emphasised that instances when a judge possesses a good or even very good knowledge of EU law are present; they still seem rather exceptional though.

The evidence for Poland clearly illustrates that many judges are likely to lack proper knowledge of institutional, procedural or material EU law. More strikingly, the

71. Nowak et al., above n. 58, at 78

72. Ibid., at 48 
Polish example shows that judges frequently do not realize whether and how EU law might be relevant for the proceedings. One of the Polish judges reflects a legal reality where the lack of knowledge and the extensiveness of EU law imply an incidental application of EU law.

We all know civil and criminal law and when we are confronted with any issue regarding those laws we know that there is one or another statute in which the issue is regulated and we know how to find it. We do not possess such knowledge with regard to EU law. I have applied some EU norms only because I came across them by accident.

Another Polish judge declares in a very straightforward way:

I do not know EU law and I cannot assess whether, when and how I am supposed to resort to it.

A Dutch judge admits that he would like to have more general knowledge of EU law, which would make it possible for her to establish some links with it. At the same time, the judge admits that due to the comprehensiveness of the EU legal order it is practically impossible to become familiar with it in more detail:

[...] That it becomes more familiar, that you get a more complete picture; that it feels more your own. I gave up the illusion that you can know all the directives. It is important that you know the system, the main directives. ${ }^{73}$

A Polish judge illustrates the complexity of situation, which could be described as a system of connected vessels. In her opinion, the judge is, at least in theory, expected to resort to and apply EU law of her own motion but due to the extensiveness of the EU body of law and the existent gaps in EU law knowledge she must rely on the input of the parties to the disputes. Those, in turn, are not always capable of substantiating their rights which may follow from EU law.

One of the reasons why EU law does not occur in the courts is the fact that parties do not signal it. Certainly in our system we have the iura novit curia principle and I guess also the ECJ is of the opinion that EU law should be applied ex officio. Anyway, attorneys are totally ignorant of EU law and are incapable of pointing out that EU law could be applicable. Even if they refer to EU law then in a very general way, for instance that the national provisions originate from a directive but further they cannot even say what that means in practice. So, it is obviously the role of the judge to know that EU law could be at stake but that's all in theory. Since we don't know EU law we must rely on the parties to show us its relevance.
As the qualitative data seem to suggest, this lack of confidence with regard to EU law may, in turn, trigger the feelings of uncertainty or even frustration among the judges and might, in some cases, results not only in legally incorrect decisions but also in attempts to avoid any EU law discourse.

\subsection{Complexity, Clarity and (Lack of) Legal Certainty}

What do judges think of the scope of EU regulatory activities and consequently the body of its law? What are the consequences of the overlapping legal orders for the principle of legal certainty? The qualitative studies reflected the reality in which a judge struggles with the scope of EU law, which she finds difficult to get acquainted with and subsequently apply in the daily practice. This in turn may have profound consequences for the constitutive principle of legal certainty. One of the Dutch judges reflects:

[...] European law has such gigantic magnitude - as a Dutch judge you already have the feeling that you only really know a small part of Dutch law; this is even more so with European law. ${ }^{74}$

A Polish judge laments that the extensiveness of EU law has become very perplexing:

The amount of EU law regulation makes one's hair rise! It is definitely harmful since the problem of finding the relevant provisions becomes very evident. The scope of this law has achieved such an extent that I heard from my friends working in the advocacy that they use the arguments of EU law just because the judge hearing the case would not be capable of finding the provision at issue!

The criticism of the scope of EU law does not end with the fact of the overgrowth and remoteness of the EU regulatory activities but also touches upon the excessive complexity of legislation. One of the Polish judges is very critical of the existent situation, which she perceives as irrational:

You know, the law is a source of income for multitude of people so for them it is definitely favorable. But the scope of it is just devastating, no one is capable of embracing it. This is obviously a very negative development for in most instances they just split hairs and search for rules in simple, straightforward situations, they multiply provisions which only pervert any logical approach to normal functioning. If you have a simple situation and in order to resolve it you must approach a group of specialists then it is outrageous, isn't it?

Moreover, as some of the judges noticed, the laws are at times not coherent and may collide with each other. A Dutch judge asked about the quality of EU law points to 
the incoherence or even contradictions between various sources of EU law:

Is it well formulated? Well, as a rule I think not. It is too much a political compromise what is put on paper. You also see in the preambles things that completely seem to contradict each other. You think that everybody laid his own egg and everybody is happy. Thus, as far as this is concerned: 'no' ${ }^{75}$

The foregoing line of arguments naturally brings another point to the discussion. In the personal narratives, many judges pointed to the principle of legal certainty and legitimate expectations as one of the problems attached to the role of EU law in the multi-level legal system. It occurs that the body of EU law has become too complex and perplexing, which makes it impossible to comprehend, even for a legal expert. In that sense, it may pose problems to individuals who cannot easily identify the sources of legal rules and consequently determine the content of those rules, that is to say their very rights and obligations. ${ }^{76}$ At the same time, it has also become perplexing for the judges who have difficulties navigating through this complex and fragmented legal architecture with its all exceptions and derogations. Consequently, many judges are likely to feel insecure when it comes to EU law or afraid that they might have missed or omitted something that would otherwise impact cases they are presiding over. A German judge notices:

It is more that there is insecurity if a lawyer mentions something. Oh my god, have I overlooked something? And then you do research and you normally find out that the lawyer just guessed. He read something somewhere without going into depth. ${ }^{77}$

In a similar vein, a Polish judge notices that the lack of knowledge combined with the scope of EU law may result in situations where a judge unintentionally bypasses EU law that would otherwise impact the outcome of the case:

[...] taking into consideration the magnitude of EU law regulations I am never really sure whether I processed with an issue correctly, whether I have not overlooked, omitted something. This feeling of anxiety is continuously present since my knowledge of EU law is too general [...] So indeed, there is a high risk that EU law elements pass by totally unnoticed $[\ldots]$

Another Polish judge points to the inner collisions in the system, its open-endedness and lack of straightforward answers. Those, in the opinion of some judges,

75. Ibid., at 43

76. N. Jansen, 'Legal Pluralism in Europe. National Laws, European Legislation, and Non-legislative Codifications', at 5, publicly available paper to be found at <http:// papers.ssrn .com/ sol3/ papers.cfm ?abstract_id= 1840356> (last accessed 22 November 2012).

77. See Nowak et al., above n. 58, at 48 . may jeopardize the coherence and uniformity of the legal system and altogether implicate more complexity in the daily work of a judge.

The problem is not with EU law as such but with all those inter-systems collisions. Because those systems overlap but in practice it does not work as smooth as you would think. EU law yes, but how to use it in a particular case? Is the local government the emanation of the state or not? Is it horizontal or vertical situation? And then all that jurisprudence! And then all the work time regulations and the results thereof.

The enormous scope and fragmented nature of EU law brings the discussion back to the lack of EU law knowledge among the judges. In view of the foregoing, it does not anymore come as a surprise that for a national judge it seems nearly impossible to get familiar with the body of EU law, including the CJEU's jurisprudence, in more detail. Next to the above-discussed and closely linked with the problem is the issue of the place and feasibility of the Court's case-law for the daily judicial practice and the activist role of the CJEU in interpreting EU law sources, which will be considered below.

\subsection{Legitimacy of the Court of Justice and Feasibility of Its Case-Law}

The final topic to be discussed concerns the issue of the role and nature of the jurisprudence of the Court of Justice and possible problems attached to its application. This problem revolves around two different aspects. On the one hand, there is the problem of the language, style and the lengthiness of the case-law, and, on the other hand, there is the issue of the active way the CJEU interprets EU law. A Dutch judge emphasises the difficulty attached to the reading of Court's judgments:

I simply find the decisions of the ECJ unreadable. The 'if $[. .$.$] then', 'and then' and 'the question of this$ and that number' and you do not even know which question it was. I find it immensely exhausting to read. $^{78}$

Similarly, a Polish judge observes:

The judgments of the Court are written in other language which is very much different from the language we are used to. So we assume that an ordinary judge will start reading any judgment of the Court then he will fall, to be honest. Here we seriously need an icebreaker to overcome the barriers in mentality and approach.

Also a German judge admits that:

It is sometimes rather difficult to understand the ECJ. ${ }^{79}$

78. Ibid., at 43. See also narratives from other judges.

79. Ibid., at 135 . See also narratives from other judges. 
A Polish judge points to the fact of the daily reality where judges may not have enough time at their disposal to embark on getting familiar with the case-law of the Court:

I have read two judgments of the Court. I don't have time to read them just like that, without a reason. They are way too long, I can't afford reading 60 pages, I have other tasks to complete.

A similar emphasis on the style and lengthiness of judgments is conveyed by another Polish judge:

Those judgments have, let's call it, Byzantine style. They are scattered and very formal. Too much description and lengthiness. It is just too much so it is understandable that judges have issues with it.

The second line of criticism regarding the Court of Justice goes beyond the mere way its judgments are formulated and touches upon the core issue of the role of the judiciary in creating legal rules. In particular, the Polish judges seem quite critical of the way the Court makes rules by resorting to the teleological method of interpretation of EU law. To some of the judges, such a method of interpretation may seem illegitimate as it undermines legal certainty.

I dislike this manner of adjudicating where they create legal rules and principles in situations where there is no legal basis for it. The CJEU makes law and that is alien to my way of perceiving the role law plays in general. A court applies the law, it mustn't make the law. I know the arguments of the Court why they do it but I do not agree with them. So you suddenly discover that there is something which in fact is not there.

\section{In a similar vein, another Polish judge observes:}

When you apply the dynamic methods of interpretation you run a great risk, you stray from the most pivotal role the law plays in the society, the stabilizing role, because you don't know what to expect, you don't know what you are standing at [...] A dynamic way of interpreting legal provisions means that from A I will arrive at $G$, that is to say A provision will become something totally different $[\ldots]$ It's a great risk.

In that sense, the Polish judges put the emphasis on the problem of judicial activism, the output legitimacy of judge-made law and the extensive use of the teleological method of interpretation, which do not necessarily fit the local legal culture and the traditionally established boundaries of the judicial functioning in some of the Member States.

\section{Conclusions}

This article has brought together theoretical and empirical insights concerning the functioning of judges in a pluralistic, multi-level legal order into one analytic frame, whereby it attempted to bridge the gap between the theoretical underpinnings of this legal structure and the manner national judges experience this structure in their daily practice.

As the theoretical part of this article illustrated, the law of the European Union puts a whole range of tasks on the national judge. It requires her to treat $\mathrm{EU}$ law as an integral part of the legal order and asks her to resort to and directly apply it in the daily practice. It obliges her to give precedence to EU law provisions and to interpret national provisions in the light of the entire legal order of the Union. It urges her to resort to the CJEU with all possible problems concerning the interpretation of $\mathrm{EU}$ law, which may occur in the processes of adjudication, and requires her to apply the case-law of the CJEU, which is the highest judicial authority for EU law issues. Nonetheless, the sections that are based on selected empirical data, even though somewhat cursory, which implies that we should be careful with generalizations, clearly show that the way the law is experienced in practice may be quite different from the way it ought to operate. For a national lower instance private law judge, EU law does not necessarily constitute an axiomatic, natural and integral part of the legal order. Often enough, it is abstract and remote, and it adds up to the complexity of the judicial process. Many judges may feel distant from the legal order of the Union and experience practical problems with resorting to it and accommodating it into the adjudication process. Hence, the assumption that EU law is everymhere and for that reason the judges should eagerly and daily resort to it seems somewhat exaggerated. The lack of proper EU law education, and consequently the lack of familiarity with EU legal sources, and the functional reasons like, for instance, lack of time and other resources only add up to the complexity of the situation. This lack of knowledge puts into question the operationalization of the most basic principles of EU law such as direct effect, harmonious interpretation or ex officio application of EU law. In a similar vein, the authority of the CJEU and its jurisprudence is not something that is axiomatic and can be taken for granted. Some of judges may even represent a sort of skepticism or cynicism towards legal rules and concerns about the legitimacy of the entire system. EU law clearly expects a different way of adjudicating; it expects to look for objectives of the EU legislation in order to ensure its effet utile, but this may at times be difficult to complete when the local legal culture and the local particularities of the judicial process do not create room, which would facilitate going beyond the mere textual interpretation of the provisions at issue. By and large, a national lower court judge is very much embedded in and attached to the national legal order, local sources of law and the locally practiced judicial method- 
ology (formalism), which in turn may influence the way judges approach and apply EU law and might, at times, compromise its effectiveness and uniformity across the Union.

The selected data presented in the foregoing sections show that judges' legal consciousness regarding EU law is very much shaped by their personal experiences with resorting to it and applying it, and their knowledge of it. That is also why legal consciousness is a somewhat emergent and fluid notion, as it may evolve in the course of time together with the gained experience and knowledge. ${ }^{80}$ This is in line with other research concerning legal consciousness of lay people in which it is claimed that legal consciousness is a process taking different forms and that a particular individual might ' $[\ldots]$ express a multifaceted and possibly contradictory consciousness'. ${ }^{81}$ Similarly to legal consciousness research regarding lay people, this research shows that judges may adopt a whole range of approaches to (EU) law, and some of those approaches may even be labeled as cynical, showing resistance or distrust to EU law and questioning its legitimacy. ${ }^{82}$ Finally, the findings of this research are consistent with other research that points to the role of the prevailing legal culture of the judiciary and the necessity for it to evolve in order to accommodate the changes brought by the new (EU) legal environment. ${ }^{83}$

The foregoing discussion shows that legal pluralism can be somewhat problematic when national courts are expected to apply legal rules that originate from a distinct, that is to say state and non-state (EU), legal orders. As the empirical data show, asking national judges of lower instance courts to treat legal sources that have their roots outside the state as an integral part of the national legal system might at times pose a challenge. The problems judges experience in that regard may be of an abstract nature, but they are frequently of a somewhat mundane, trivial character. The results also emphasise the problems incurred by the comprehensiveness of the pluralistic legal order and the intensity of EU regulatory processes. The foregoing should be seen in the light of the very nature of the work courts of lower instance are performing, which often boils down to finding swift solutions to hundreds of more or less complicated disputes. This constitutive task becomes more complex and intricate if the judge deals with a multilevel legal structure. All in all, in a legal order that rests on state and non-state legal sources that together establish a fragmented legal jungle, ${ }^{84}$ a national judge may at times be lost and overwhelmed. This, in turn, may jeopardize legal certainty for both the judges themselves and the individuals standing before them. Yet, the existence of such a complex legal order may also create opportuni- ties for individuals who may try to advance their objectives by resorting to non-state legal sources. However, those opportunities seem to be reserved for those who simply can afford a good and skilled lawyer. ${ }^{85}$

82. See for instance Ewick and Silbey (1998), above n. 26; Engel, above n.23, and Nielsen, above n. 31, at 1083 and next.

83. See M. Hunt, 'The Human Rights Act and Legal Culture: The Judiciary and the Legal Profession', 26 Journal of Law and Society, 86 (1999).

84. For the problem of fragmentation of the law see Jansen, above n. 76.

85. See B.Z. Tamanaha, above n. 1, at 375, where he claims, 'This state of conflict also creates opportunities for individuals and groups within the society, who can opportunistically select from among coexisting legal authorities to advance their aims.' 